\title{
Ю.Н. Кравцова
}

\section{Средние общеобразовательные учреждения Екатеринодара} и их деятельность в дореволюционный период

\section{Аннотация}

В данной статье рассматривается основные особенности процесса формирования и развития образования на Кубани. Образование имеет огромное значение в жизни любого современного общества. От него зависит уровень научно-технического прогресса, экономическое развитие, социальная дифференциация населения. Основные принципы российской системы образования были сформированы еще в дореволюционный период. Именно тогда были заложены довольно высокие требования учебно-воспитательного процесса.

Ключевые слова: образование, гимназии, училища.

\section{Iu.N. Kravtsova \\ General Education Schools of Yekaterinodar and Their Operations in Pre-Revolutionary Period}

\section{Abstract}

The following article examines the basic features of the formation and development of education in Kuban. Education plays an important role in the life of modern society. The level of scientific and technological progress, conomic development, social differentiation of population depends on education. The basic principles of the Russian educational system have been established during the pre-revolutionary period. It was then when rather high requirements of educational-bringing-up process were set.

Keywords: education, gymnasiums, academies.

B то время одним из самых главных культурно-просветительских центров Северного Кавказа без сомнения являлся город Екатеринодар. К началу ХХ в. здесь сложилась довольно разнообразная сеть учебных заведений. Наиболее значимыми из них были учреждения средней общедоступной школы: гимназии и реальные училища. Они были открыты для широких кругов населения и предоставляли довольно высокий уровень знаний, их выпускники составили основу для местной интеллигенции, высококвалифицированных рабочих и торгово-промышленных групп.

Развитие образования на Кубани шло в полном соответствии с общероссийскими реалиями. Зарождение системы народного образования на Кубани берет свое начало со времени переселения сюда Черноморского казачьего войска. С закладкой станиц и крупных укреплений организовывались специализированные хаты-школы «У церковных причетников». В них обучали лишь чтению и письму, а занятия вели лица духовного сословия и писари. Обучение грамоте также производилось при казачьих канцеляриях.
Первая официальная школа появилась лишь в Екатеринодаре в 1803 г. (в 1804 г. получила статус войскового училища. В 1820 г. в Екатеринодаре по инициативе первого кубанского просветителя К. Россинского была открыта Черноморская войсковая гимназия.

По уставу войсковая гимназия была рассчитана на семь классов, и в целом приравнивалась к губернским гимназиям. Несмотря на то, что официально войсковая гимназия имела сословный ценз, и там должны были обучаться исключительно дети дворян и чиновников, но начальство по факту разрешало посещение учебного заведения представителям других сословий. С учреждением войсковой гимназии было закрыто Екатеринодарское уездное училище, в котором оставались только младшие классы.

Войсковая гимназия обладала достаточно высоким уровнем педагогического процесса. Современники отмечали наличие в ней «довольно порядочной» библиотеки и минералогического кабинета. Выпускники гимназии удостаивались похвального аттестата, а при поступлении на государственную службу производи- 
лись в первый официальный чин (рядовые дворяне через один год, дети дворян - через три года, прочие - через пять лет действительной службы.

В 1890 г. Кубанская войсковая гимназия была упразднена, вместо нее в городе открыта новая «полная гимназия с отнесением расходов по ее содержанию на городские средства». Вскоре она была названа в честь бывшего городского головы «1-й мужская гимназия имени В.С. Климова». По замечанию современников гимназия обладала высокой репутацией, так как в ней преподавали 16 учителей, получивших образование в лучших университетах страны (Петербургском, Московском, Харьковском, Юрьевском университетах), два «законоучителя» окончили Московскую и Казанскую духовные академии.

Первые женские среднеобразовательные учреждения в Екатеринодаре появились в пореформенный период. 25 октября 1860 г. Александр II утвердил положение о Мариинском училище Кубанского казачьего войска, однако его создание было отложено почти на три года в связи с непрекращающимися военными действиями в Закубанье. В организации данного училища как никогда была особая значимость меценатов. Наказной атаман Кубанского войска, его жена, и даже сам император ассигновали значительные суммы на новое учреждение. Торжественное открытие училища состоялось в октябре 1863 г.

Согласно Положению, в училище на безвозмездной основе могли обучаться «девочки всех чинов Кубанского казачьего войска и лица разных званий и вероисповеданий, к этому войску не принадлежащих». С представительниц купеческого звания взималась годовая плата 10 руб. серебром. В пансион при училище на полное казённое и полуказённое содержание принимались дочери офицеров Кубанского казачьего войска «недостаточного состояния», преимущественно сироты. «Своекоштными пансионерками» принимались дочери офицеров, чиновников и священнослужителей Кубанского казачьего войска и иногородних лиц, служащих в войске».

Все расходы на содержание училища несло Кубанское казачье войско. Кроме того, при училище действовал попечительский совета, его первым председателем была жена начальника Кубанской области генерал-лейтенанта графа Ф.Н. Сумарокова-Эльстона.

Первый набор состоял из 84 девушек. В 1864 г. был открыт пансион на 30 учениц (из них 28 воспитанниц было определено на полное войсковое обеспечение). Возраст для принятия в пансион - от восьми до тринадцати лет.

Главной задачей Кубанского Мариинского женского училища ставилось воспитание дочерей офицеров Кубанского казачьего войска, «соответствующее их будущему назначению - быть добрыми супругами, попечительными матерями, на которых исключительно лежит обязанность о физическом воспитании и первоначальном умственном образовании детей, быть знающими хозяйками, от которых большей частью будет зависеть домашнее благосостояние». По окончании учебного заведения ученицы, не подвергаясь особому испытанию, получали свидетельства на звание домашней учительницы.

В 1902 г. особым рескриптом Николай II «Высочайше соизволил» переименовать училище в «Кубанский
Мариинский женский институт». При этом император выражал уверенность, что новый институт «будет и впредь делать России... воспитанных на незыблемых истинно-христианских началах девиц, которые, возвратясь под родительский кров, сделавшись сами матерями семейств или подвизаясь на педагогическом поприще, будут применять в жизни, освоенные в родном им заведении правила благочестия, преданности Престолу и Отечеству и любовь к просвещению».

В 1909 г. было отстроено новое кирпичное здание Кубинского Мариинского женского института - одного из самих больших и красивых в городе (см: Приложение Б). При Советской власти в них размещались военные училища, ныне - Краснодарское военное училище имени генерала С.М. Штеменко.

В 1910-1911 гг. «по высочайшему утверждению» в институте открылись 8-е педагогические классы с отделениями «педагогичек», «словесниц» и «математичек».

По расчетам С. Калайтана за полвека своего существования Екатеринодарского Мариинского женского училища было произведено 44 выпуска и в совокупности его окончили 950 девушек. Из них около 10\% впоследствии стали школьными учительницами.

В 1881 (1884) г. в Екатеринодаре появилась первая Женская гимназия, первоначально она находилась в здании, где были параллельные классы Мариинского женского училища. Ее почетной попечительницей была супруга наказного атамана Кубанской области - Елизавета Ивановна Малама. В 1897 г. при 11 учителях в ней обучалось 533 гимназистки.

Одним из главных центров образования на Кубани в дореволюционный период являлось Кубанское Александровское реальное училище, торжественно открытое 2 октября 1880 г. в городе Екатеринодаре. Первоначально оно размещалось в частном доме. Лишь в 1891 г. ему было передано здание войсковой гимназии, расположенное в самом центре города (см: Приложение Б).

Первый набор учащихся состоял всего из 60 детей. Но уже через несколько лет после открытия оно стало лучшим среди средних общеобразовательных заведений Кавказского учебного округа.

Преподавательский коллектив состоял из высоко квалифицированных специалистов, получивших образование в Петербургском, Московском, Харьковском университетах, Строгановском рисовальном училище и других престижных учебных заведениях страны. Во многом это было обеспечено благодаря щедрому финансированию. На содержание училища и пансиона в конце XIX в. ежегодно расходовалось около 40 тысяч рублей.

В 1911 г. в Екатеринодаре было открыто второе реальное училище для детей всех сословий. После этого содержание Кубанского Александровского реального училища полностью перешло на средства Кубанского казачьего войска. Теперь дети нижних чинов составляли две трети от числа учащихся.

Развитию образования в Кубанской области и в Екатеринодаре значительно мешало отсутствие во всем Кавказском учебном округе высших учебных заведений. Выпускникам екатеринодарских средних школ, 
желающим поступить в университет или институт приходилось отправляться в другие крупные города России и выдержать дополнительную конкуренцию. Однако екатеринодарские гимназии и реальные училища давали довольно высокий уровень знаний, позволявший выдерживать подобное соперничество. Только Московский университет в 1877-1916 гг.закончили 129 студентов из Кубанской области, то есть в среднем за год из стен университета выходили 3 дипломированных специалиста-кубанца. Многие из них отличались. Например, выпускник юридического факультета 1903 г. Б.А. Игнатьев, удостоенный дипломом II степени (что обеспечивало чин XII класса - губернского секретаря), ранее закончил Екатеринодарскую городскую гимназию с золотой медалью.

На рубеже XIX-XX вв. в Екатеринодаре было открыто несколько новых образовательных учреждений. В 1906 г. существовали следующие средние учебные заведения:

Одна мужская гимназия, рассчитанная на шесть классов - (490 гимназистов); (при ней находилась прогимназия, имевшая два обязательных и один дополнительный класс (86 гимназистов);

Кубанское Александровское реальное училище, имевшее семь классов, и один дополнительный класс (539 реалистов); 1-я и 2-я женские гимназии, имевшие соответственно семь обычных и один педагогический класс и пять классов) - (584 и 130 гимназисток).

В 1914 г. число средних учебных заведений в Екатеринодаре значительно выросло и достигло шестнадцати учреждений, где обучалось свыше шести тысяч учащихся: 1-я и 2-я мужские гимназии - соответственно - 532 и 507 учащихся; 1-я, 2-я и 3-я женские гимназии - 648, 532, 305; Кубанское Александровское реальное училище - 512; Екатеринодарское, второе реальное училище - 196; Коммерческое училище - 320; Мариинский женский институт - 522; Епархиальное женское духовное училище - 507; Кубанская учительская семинария 130; Женское училище - 122; Духовное училище - 290; Военно-фельдшерская школа - 1034; Сельскохозяйственная школа - 73; Торговая школа -53 .

Подобные обстоятельства обусловили довольно высокий по российским меркам уровень грамотности населения. К 1913 г. она составляла 47,1 процентов, в 1917 г. на каждые 100 человек приходилось 43 грамотных казака и 17 казачек.

Итак, в течении XIX в. в Екатеринодаре возникли все основные виды общих среднеобразовательных учебных заведений, что стало одним из факторов высокого уровня образования местного населения.

\section{Литература}

1. Высочайше утвержденный Устав Учебных заведений, подведомственных университетам. 5 ноября 1804 г. // Полное собрание законов Российской империи. - Собрание 1-е. - Т. XXVIII. - СПб., 1830. - С. 626-647.

2. Устав гимназий и училищ уездных и приходских, состоящих в ведомстве Университетов. 8 декабря 1828 г. // Полное собрание законов Российской империи. - Собрание 1-е. - Т. III. - СПб., 1830. - С. 1097-1127.

3. Устав гимназий и прогимназий Министерства Народного Просвещения. 1864 г. // Сборник постановлений по Министерству Народного Просвещения. - Т. ІІІ. Царствование Императора Александра II (1855-1864). - СПб., 1876. - C. $600-631$

4. Устав гимназий и прогимназий Министерства Народного Просвещения. 1871 г. // Сборник постановлений по Министерству Народного Просвещения. - Т. V. Царствование Императора Александра II (1871-1873). - CПб., 1877. - C. 431-464.

5. Высочайше утвержденный устав реальных училищ Министерства Народного Просвещения. От 15 мая 1872 г. // Полное собрание законов Российской Империи. - Собрание 2-е. - Том 47. - СПб., 1873. - С.626-636.

6. Женские гимназии и прогимназии Министерства народного просвещения. 1858-1905. - Спб., Департамент нар. просвещения, 1905. - 139 с.

7. Народное образование и педагогическая мысль России кануна и начала империализма (Малоисследованные проблемы и источники): Сб. научных трудов / Под ред. Э.Д. Днепрова. - М.: АПН СССР, НИИ общей педагогики, 1980. - 295 с.

8. Ганелин, Ш.И. Очерки по истории средней школы в России второй половины ХІХ века / Ш. И. Ганелин. - М.: Мин-во просвещения РСФСР, 1954. - 303 с.

9. Исторический очерк. Женские гимназии прогимназии по Положению 24 мая 1870 года / б.а. - 201 с.

\section{References}

1. (1830). Vysochaishe utverzhdennyi Ustav Uchebnykh zavedenii, podvedomstvennykh universitetam. 5 noiabria 1804 g. Polnoe sobranie zakonov Rossiiskoi imperii, Sobranie 1, , 626-647. SPb.

2. (1830). Ustav gimnazii i uchilishch uezdnykh i prikhodskikh, sostoiashchikh v vedomstve Universitetov. 8 dekabria 1828 g. Polnoe sobranie zakonov Rossiiskoi imperii, Sobranie 1, , 1097-1127. SPb.

3. (1876). Ustav gimnazii i progimnazii Ministerstva Narodnogo Prosveshcheniia. 1864 g. Sbornik postanovlenii po Ministerstvu Narodnogo Prosveshcheniia, 600-631. SPb.

4. (1877). Ustav gimnazii i progimnazii Ministerstva Narodnogo Prosveshcheniia. 1871 g. Sbornik postanovlenii po Ministerstvu Narodnogo Prosveshcheniia, T. V. Tsarstvovanie Imperatora Aleksandra II (1871, 431-464. SPb.

5. (1873). Vysochaishe utverzhdennyi ustav real'nykh uchilishch Ministerstva Narodnogo Prosveshcheniia. Ot 15 maia 1872 g. Polnoe sobranie zakonov Rossiiskoi Imperii, Sobranie 2, . SPb. 
6. Zhenskie gimnazii i progimnazii Ministerstva narodnogo prosveshcheniia. 1858-1905., 139.

7. Dneprova, E. D. Narodnoe obrazovanie i pedagogicheskaia mysl' Rossii kanuna i nachala imperializma (Maloissledovannye problemy i istochniki): Sb. nauchnykh trudov., 295.

8. Ganelin, Sh. I. (1954). Ocherki po istorii srednei shkoly v Rossii vtoroi poloviny XIX veka., 303. M.: Min-vo prosveshcheniia RSFSR.

9. Istoricheskii ocherk. Zhenskie gimnazii progimnazii po Polozheniiu 24 maia 1870 goda., 201. 